\title{
Frequency and Characteristics of Dust Sediments in Core Samples from Hashylan Wetland, Kermanshah, Iran
}

\author{
Esmail Namdadi' ${ }^{1}$, Mostafa Karimian Eghbal1 ${ }^{*}$, Nikou Hamzehpour ${ }^{2}$ \\ ${ }^{1}$ Soil Science Department, Tarbiat Modares University, Tehran, Iran \\ ${ }^{2}$ Soil Science Department, Maragheh University, Maragheh, Iran \\ Email: *mkeghbal@modares.ac.ir
}

Received 18 January 2016; accepted 11 March 2016; published 14 March 2016

Copyright (C) 2016 by authors and Scientific Research Publishing Inc.

This work is licensed under the Creative Commons Attribution International License (CC BY). http://creativecommons.org/licenses/by/4.0/

(c) (i) Open Access

\begin{abstract}
Dust phenomenon is one of the biggest environmental problems in arid and semiarid regions. In these areas, lakes and wetlands are natural dust traps and core sampling method can be an appropriate way to assess the phenomenon of the dust. Therefore, the purpose of this study is the study of frequency and characteristics of dust sediments in core samples from Hashilan wetlands, Kermanshah. Four intact core samples were taken from different parts of the Hashilan wetland in Kermanshah. Physical, chemical and micromorphological analysis were done. Also clay mineralogy was performed using X-ray analysis (XRD) and shape of particles was photographed by scanning electron microscope (SEM). Considering that four samples had been taken from different parts of the wetland, the quantitative differences in dust amount are likely due to the location of the samples. The results of XRD and thin sections show that the dominant mineralogical composition of dust particles was clay minerals, quartz and calcite. SEM results for core sample 1 revealed that most particles had the size between 2 to $50 \mathrm{~mm}$ which ranged from fine silt to coarse silt. Considering the similarities between SEM images for core sample 1 and those from Kermanshah dust measurement station, it could be said that fine rounded particles detected at top $30 \mathrm{~cm}$ of core samples had Aeolian origin. These findings were in accordance with the results from dust measurement and weather station of Kermanshah about increased dust activities in the study area over past 10 years.
\end{abstract}

\section{Keywords}

Core sampling, Dust, Micromorphology, Mineralogy

\footnotetext{
${ }^{*}$ Corresponding author.
}

How to cite this paper: Namdadi, E., Eghbal, M.K. and Hamzehpour, N. (2016) Frequency and Characteristics of Dust Sediments in Core Samples from Hashylan Wetland, Kermanshah, Iran. Journal of Geoscience and Environment Protection, 4, 17-28. http://dx.doi.org/10.4236/gep.2016.43002 


\section{Introduction}

Dust phenomenon is one of the biggest environmental problems in many parts of the world. It is composed of fine grain particles and is mostly common in arid and semiarid regions due to lack of rainfall and low vegetation cover [1]. Every year between 0.5 to 5 billion tons of fine particles are being carried from their original source to different parts of the world by dust storms [2], 75\% of which are deposited on lands and 30\% in oceans [3].

Two third of Iran are located in arid and semi-aridzones and with the rainfall half the annual average of the world, this country is exposed to local and regional dust phenomenon [4]. Several sources of dust have been recognized and studied in Asia e.g. [5]-[9]. Iran is surrounded by some of the biggest dust generating areas in the world, e.g. Iraq and Syria deserts in west, Saudi Arabia in south and southeast and Aral Lake in north [10]. Tigris and Euphrates watershed near western provinces of Iran are the origin of the strong dust storms which happen during spring and summer times and are probably accelerated by those from Saudi Arabia [11]. Resulting dust particles can cover a wide area, from Iran to Indian Ocean [12]. Several methods of dust measurement have been developed worldwide and an outstanding review on dust modelling and monitoring is summarized by [3].

Among all methods of dust studies, core samples from lacustrine sediments have also been used successfully to study the windblown particles deposited in underlay sediments of lakes. This method can be used in study and recognition of dust with regional or local origins [13]-[19]. Although there have been several studies on Aeolian particles, their origin, mineralogy etc. in Iran [20]-[22], core sampling method hasn't been used in Iran to study the origin and characteristics of dust. Therefore, the aim of this study is to use core samples from Hashilan Wetland in Kermanshah province to study the origin, characteristics and frequency of dust particles deposited in undelay sediments of the wetland.

\section{Materials and Methods}

\subsection{Study Area}

The study area is located in Hashilan wetland, $36 \mathrm{~km}$ to the Northeast of Kermanshah Province, Iran. It is between $46^{\circ} 15^{\prime} 54^{\prime \prime} \mathrm{E}$ and $34^{\circ} 34^{\prime}$ to $34^{\circ} 34^{\prime} \mathrm{N}$ with an area of 450 ha (Figure 1). Its elevation from sea level is 1310 $\mathrm{m}$ and the mean annual rainfall is $451 \mathrm{~mm}$. Wind blows from different directions throughout the year. Geologically, Hashilan wetland belongs to Terias-Jorasic and lithologically is composed of dense fossil licious carbonates.

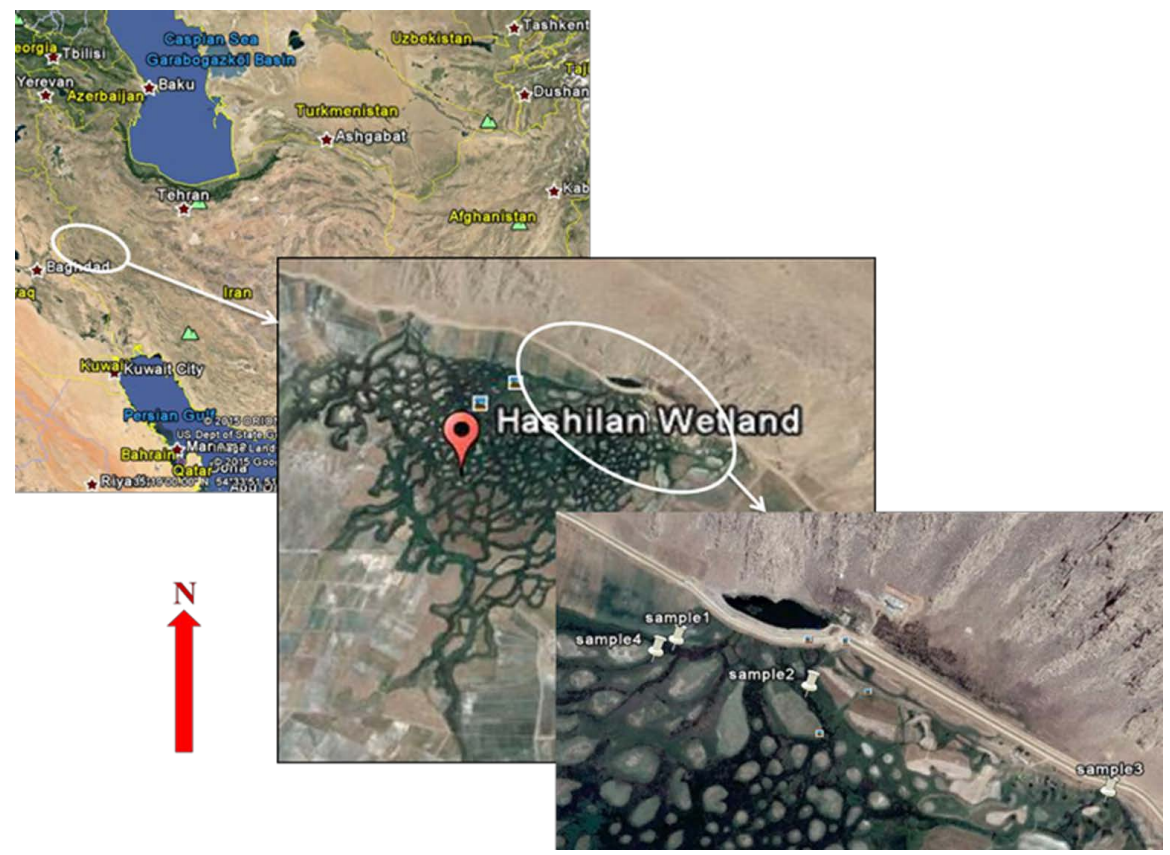

Figure 1. Location of the study area and sampling points in Hashilan wetland, Northeast Kermanshah, Iran. 


\subsection{Sampling}

The location, depth of water in sampling point and also the length of core samples are presented in Table 1. Samples were taken from underlay sediments of Hashilan wetland in 4 different locations using 5 inch in diameter polyethylene tubes (Figure 2).

\subsection{Analysis}

After removing the polyethylene tubes, each core sample was divided to $10 \mathrm{~cm}$ sections and were dried in $50^{\circ} \mathrm{C}$ for one week. Soil texture (pipet method), organic carbon (\%) (Walkly and black method), TNV, pH and EC (1:2.5 soil to water suspension) were measured in the laboratory. Mineralogical analyses on oriented samples were also done using an X-ray diffraction instrument.

In order to study the micromorphological properties of samples, 16 thin sections from 4 core samples (4 from each core sample) were prepared and analysed in PPL and XPL lights using polarized microscope and described using Stoops (2003) handbook.

To compare the Aeolian particles trapped in sediments of core samples from Hashilan wetland with samples from dust measurement station of Kermanshah, scanning electron microscope (SEM) analysis of sample 1 were done using SEM device model Philips XL30.

\section{Results and Discussion}

\subsection{Physicochemical Properties of Core Samples}

Summary of physicochemical properties of core samples are presented in Table 2. In core sample 1, texture changes from silty clay in the top $50 \mathrm{~cm}$ to clay in the depth $50-70 \mathrm{~cm}$. Mean geometric diameter of grain size (dg) analysis revealed that fine silt is the prominent particle size in sample $1 . \mathrm{CaCO}_{3}$ content remained almost constant through top $30 \mathrm{~cm}$ but showed a significant and sudden decrease in part 1-5 (depth 40 - 50). Here, in part 1-5 soil organic carbon also showed a distinct increase in comparison to the previous layer (from $0.52 \%$ to 4.29\%), giving us the idea that sedimentation processes have changed significantly between these two parts and a sedimentation discontinuity has occurred in depth $30 \mathrm{~cm}$ of core sample 1 (Table 2, profile 1).

In core sample 2, texture was very fine and clayey in top $20 \mathrm{~cm}$ and unlike other 3 core samples, $\mathrm{CaCO}_{3}$ content increased from upper layers to the bottom of the sample. In core sample 3 , texture was silty clay through whole sample and $\mathrm{CaCO}_{3}$ and O.C decreased from top of the sample to the bottom (Table 2). In core sample 4,

Table 1. Geographic location, water depth in each sampling point and the length of core samples.

\begin{tabular}{|c|c|c|c|c|}
\hline Sample No. & Latitute (N) & Longitute (E) & Water Depth & Sample Lenght \\
\hline 1 & $34^{\circ} 35^{\prime} 02^{\prime \prime}$ & $46^{\circ} 53^{\prime} 20^{\prime \prime}$ & $80 \mathrm{~cm}$ & $70 \mathrm{~cm}$ \\
\hline 2 & $3434 ' 58^{\prime \prime}$ & $466^{\circ} 53^{\prime} 33^{\prime \prime}$ & $60 \mathrm{~cm}$ & $50 \mathrm{~cm}$ \\
\hline 3 & $34^{\circ} 34^{\prime} 49^{\prime \prime}$ & $46^{\circ} 54^{\prime} 02^{\prime \prime}$ & $150 \mathrm{~cm}$ & $60 \mathrm{~cm}$ \\
\hline 4 & $34^{3} 35^{\prime} 01^{\prime \prime}$ & $46^{\circ} 18^{\prime} 53^{\prime \prime}$ & $70 \mathrm{~cm}$ & $70 \mathrm{~cm}$ \\
\hline
\end{tabular}

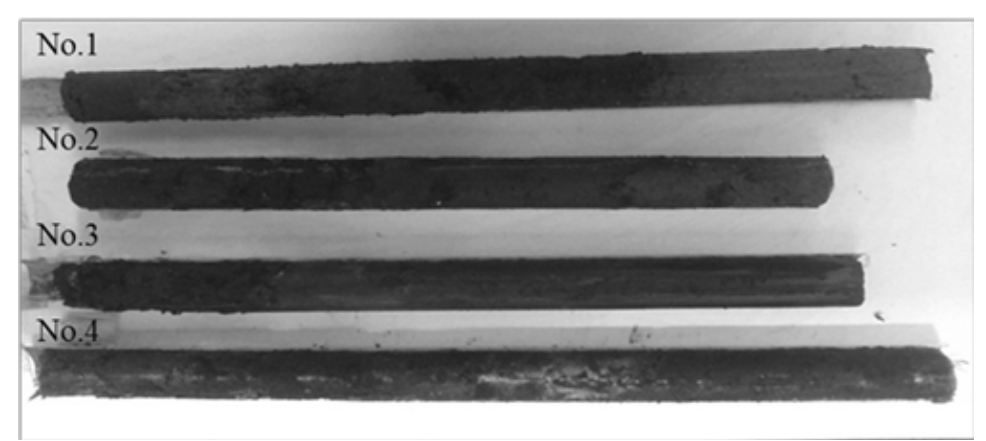

Figure 2. Core samples of underlay sediments from 4 different locations of Hashilan Wetland. 
texture was clay loam through top $30 \mathrm{~cm}$ and sandy clay loam in the rest of the sample. Through the entire core samples, EC and $\mathrm{pH}$ values were relatively similar and no significant differences were observed. But, the percentage of $\mathrm{CaCO}_{3}$ and O.C varied at different parts of the samples and also among different core samples. This can be due to the variation in vegetation cover in different parts of the Hashilan Wetland and also the distance from the Karstic springs.

In core sample 1, part 1 , different minerals were detected and those with fine silt size were more common. Quartz and calcite were the dominant minerals (Figure 2 and Table 3). The size of Calcite minerals were between 5 to 95 micrometer and considering their shape, they could have both alluvial and Aeolian sources. Quartz minerals were mostly in fine silt size and had rounded shape which could raise the possibility of their Aeolian source rather than being alluvial. Taking into account the roundness of some of the quartz minerals and fine size of the most observed minerals in core sample 1 , it seems that minerals beside having alluvial source, could also have extra-regional origin, meaning that they are being carried to the study area by wind and trapped in Hashilan Wetland (Costantini et al., 2009; Hojati et al., 2012).

Table 2. Physico-chemical analysis of core samples.

\begin{tabular}{|c|c|c|c|c|c|c|c|c|}
\hline Profile & Layer & Depth & Texture & dg (mm) & $\mathrm{CaCo}_{3}(\%)$ & OC (\%) & EC (ds/m) & pH \\
\hline \multirow{5}{*}{1} & $1-1$ & $0-10$ & Silty clay & 0.011 & 38.75 & 3.3 & 0.283 & 7.37 \\
\hline & $1-2$ & $10-20$ & Silty clay & 0.012 & 41.75 & 2 & 0.305 & 7.68 \\
\hline & $1-3$ & $20-30$ & Silty clay & 0.014 & 43.75 & 0.52 & 0.35 & 7.77 \\
\hline & $1-5$ & $40-50$ & Silty clay & 0.007 & 4.75 & 4.29 & 0.243 & 7.2 \\
\hline & $1-7$ & $60-70$ & clay & 0.003 & 52.5 & 1.3 & 0.215 & 7.9 \\
\hline \multirow{4}{*}{2} & $2-1$ & $0-10$ & Clay & 0.009 & 5.75 & 3.7 & 0.126 & 7.1 \\
\hline & $2-2$ & $10-20$ & Clay & 0.01 & 5.75 & 3.7 & 0.126 & 7.1 \\
\hline & $2-3$ & $20-30$ & Silty clay loam & 0.017 & 31.2 & 2.6 & 0.1 & 7.6 \\
\hline & $2-5$ & $40-50$ & Silty clay loam & 0.017 & 18.75 & 4.3 & 0.157 & 7.35 \\
\hline \multirow{4}{*}{3} & $3-1$ & $0-10$ & Silty clay & 0.01 & 19.75 & 3.9 & 0.294 & 7.23 \\
\hline & $3-2$ & $10-20$ & Silty clay & 0.009 & 14.75 & 2.1 & 0.334 & 7.38 \\
\hline & $3-3$ & $20-30$ & Silty clay & 0.008 & 3.75 & 1.7 & 0.311 & 7.43 \\
\hline & $3-6$ & $50-60$ & Silty clay & 0.008 & 3 & 1.4 & 0.212 & 7.60 \\
\hline \multirow{4}{*}{4} & $4-1$ & $0-10$ & Clay loam & 0.028 & 22.5 & 4.3 & 0.16 & 7.36 \\
\hline & $4-2$ & $10-20$ & Clay loam & 0.031 & 22.5 & 4.3 & 0.16 & 7.57 \\
\hline & $4-3$ & $20-30$ & Clay loam & 0.035 & 8.75 & 1.6 & 0.348 & 7.35 \\
\hline & $4-7$ & $60-70$ & Sandy clay loam & 0.06 & 6.25 & 4.4 & 0.168 & 7.27 \\
\hline
\end{tabular}

Table 3. Micromorphological characteristics of the thin section 4 of the core sampling.

\begin{tabular}{|c|c|c|c|c|c|c|}
\hline Core sample & Layer & $\mathrm{c} / \mathrm{f}$ ratio $(10 \mu \mathrm{m})$ & Microstructure $^{\mathrm{a}}$ & Porosity $^{\mathrm{b}}(\%)$ & Mineralogical $^{\mathrm{C}}$ & Source \\
\hline \multirow{5}{*}{1} & $1-1$ & $30 / 70$ & Gra & $\mathrm{PV}, \mathrm{Ch}=30-40$ & Qtz, Ca & alluvial, eolian \\
\hline & $1-2$ & $30 / 70$ & Cru & $\mathrm{PV}, \mathrm{Vu}=40-50$ & Qtz, Ca, Fm & alluvial, eolian \\
\hline & $1-3$ & $40 / 60$ & Gra & $\mathrm{PV}, \mathrm{Vu}=50$ & Qtz, Ca, Fm & alluvial, eolian \\
\hline & $1-5$ & $20 / 80$ & Gra & $\mathrm{PV}, \mathrm{Ch}=40-50$ & Qtz, Fel & alluvial, eolian \\
\hline & $1-7$ & $10 / 90$ & ABK & $\mathrm{Ch}, \mathrm{Vu}=10-20$ & $\mathrm{Ca}, \mathrm{Cm}$ & alluvial \\
\hline \multirow{3}{*}{2} & $2-1$ & $10 / 90$ & Gra & $\mathrm{PV}, \mathrm{Vu}=30-40$ & Qtz, Fm & alluvial, eolian \\
\hline & $2-2$ & $30 / 70$ & Gra & $\mathrm{PV}, \mathrm{Ch}=40$ & $\mathrm{Ca}, \mathrm{Fm}$ & alluvial, eolian \\
\hline & $2-5$ & $20 / 80$ & Gra & $\mathrm{PV}, \mathrm{Vu}=50$ & Qtz, Fm & alluvial, eolian \\
\hline \multirow{4}{*}{3} & $3-1$ & $10 / 90$ & SBK & $\mathrm{Ch}=50-60$ & $\mathrm{Ca}, \mathrm{Fm}$ & alluvial, eolian \\
\hline & $3-2$ & $30 / 70$ & SBK & $\mathrm{PV}, \mathrm{Ch}=40$ & $\mathrm{Ca}, \mathrm{Fm}$ & alluvial, eolian \\
\hline & $3-3$ & $20 / 80$ & ABK & $\mathrm{PV}, \mathrm{Ch}=30$ & $\mathrm{Fm}$ & alluvial, eolian \\
\hline & $3-6$ & $10 / 90$ & $\mathrm{ABK}$ & $\mathrm{Vu}, \mathrm{Ch}=20$ & $\mathrm{Fm}$ & alluvial, eolian \\
\hline \multirow{4}{*}{4} & $4-1$ & $30 / 70$ & Gra & $\mathrm{PV}, \mathrm{Ch}=40$ & Qtz, Fel, Fm & alluvial, eolian \\
\hline & $4-2$ & $20 / 80$ & Cru & $\mathrm{PV}, \mathrm{Ch}=30-40$ & Qtz, Ca, Fm & alluvial, eolian \\
\hline & $4-3$ & $30 / 70$ & Gra & $\mathrm{PV}, \mathrm{Ch}=30-40$ & Qrz, Fel, Fm & alluvial, eolian \\
\hline & $4-7$ & $30 / 70$ & Mas & $\mathrm{PV}, \mathrm{Ch}=50$ & $\mathrm{Fm}$ & alluvial, eolian \\
\hline
\end{tabular}

${ }^{\mathrm{a}} \mathrm{SBK}=$ subangular blocky, $\mathrm{ABK}=$ angular blocky, Gra = granules, $\mathrm{Cru}=$ crumbs, Mas = massive; ${ }^{\mathrm{b}} \mathrm{PV}=$ pauking voids, $\mathrm{Ch}=$ channels, $\mathrm{Vu}=\mathrm{vughs}$; ${ }^{\mathrm{c}} \mathrm{Qtz}=$ quartz, $\mathrm{Ca}=$ calcite, $\mathrm{Fel}=$ feldspar, $\mathrm{Cm}=$ clay minerals, $\mathrm{Fm}=$ fine minerals. 
Results of thin section studies in different parts of the core sample 1 showed that a variety of particles with different size, shape and mineralogy were observed. These particles had very fine grain size; they were rounded and mineralogically un-differentiable. These particles were more common in parts 1-2 and 1-3.

The SEM images from fine-grained particles of core sample 1 were compared to those from dust samples of Kermanshah dust measurement station. Results showed that both particles from core sample 1 and Kermanshah dust measurement station were similar in their size and shape. The significant variation in course to fine ratio (c/f) of thin sections from top of the core sample to the bottom (Table 3), showed that sedimentation environment and processes might have changed through time, which could be due to the addition of windblown dust to the Hashilan Wetland undelay sediments. According to thin section studies, Aeolian sediments had the lowest amount in parts 1-5 and 1-7 and most of the fine grain sediments observed in these two parts were clayey with alluvial origin (Figure 3).
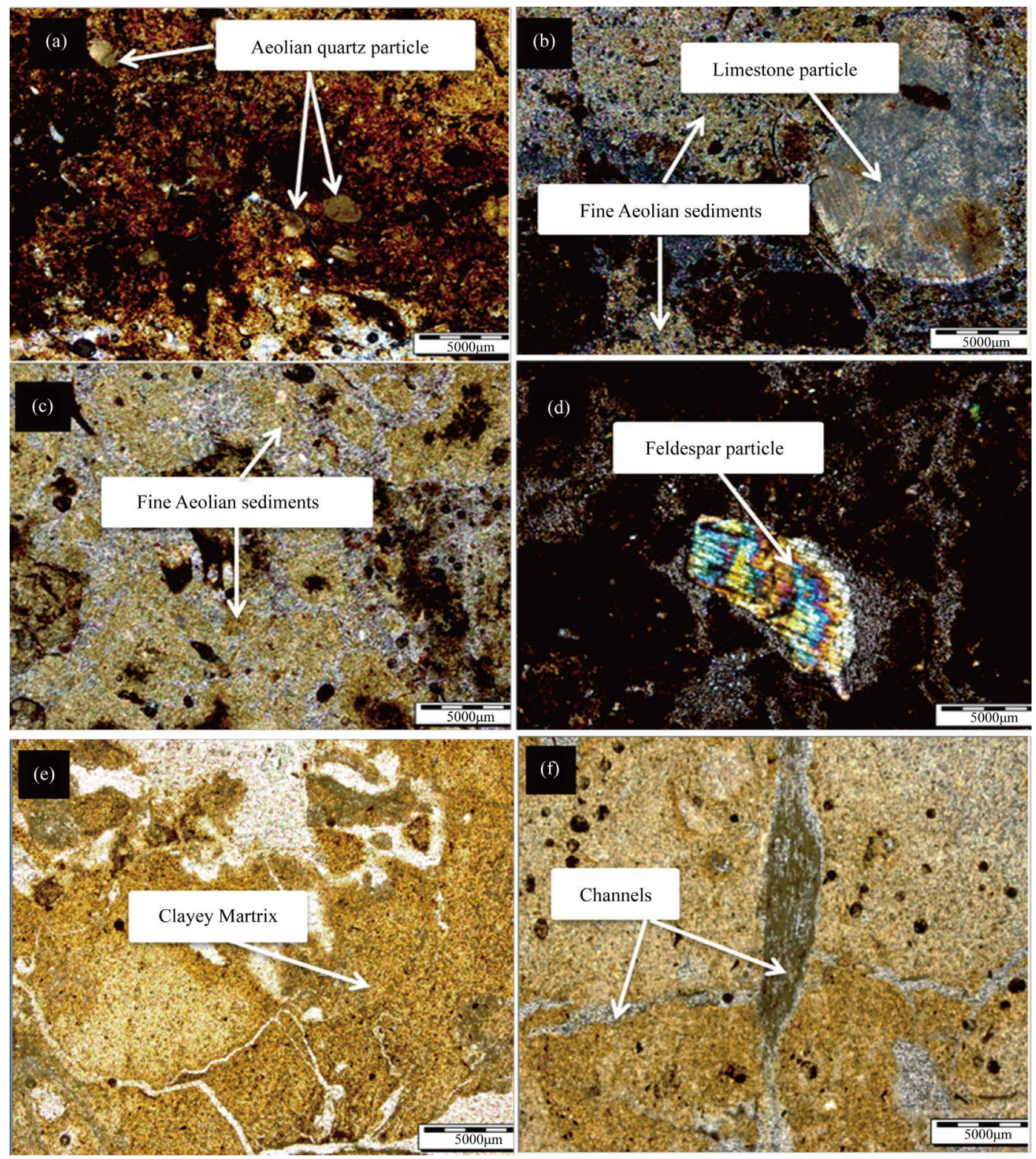

Figure 3. Thin section images from different parts of the core sample1 under polarized light. (a) Part 1-1: rounded quartz minerals in silt size; (b) Part 1-2: limestone particle and Aeolian fine sediments; (c) Part 1-3: Aeolian fine sediments; (d) Part 1-5: alluvial feldspar mineral; (e) and (f) Part 1-7: clayey matrix and channels with lesser amounts of silt size Aeolian particles. 
XRD analysis showed that quartz, clay minerals and calcite were the prominent minerals in different parts of the core sample1, which means that particles with 20 - 30 micrometer size (fine to coarse silt) are common in the sample especially at the top $30 \mathrm{~cm}$ of the core sample. This could be due to the increased amount of Aeolian dust which has entered from West and Southwest of Iran during past few years.

\subsection{Micromorphological Analysis of Core Sample 2}

In the core sample 2, part 2-1 $(0-10 \mathrm{~cm})$ had higher $\mathrm{c} / \mathrm{f}$ ratio in comparison to core sample 1 and also the rest of the core sample 2 (Table 3). This has happened due to the abundance of pores related to plants roots (Figure 4) resulting in movement of fine alluvial and Aeolian sediments downward and their concentration in the lower parts, where the sediments are more condensed. In different parts of the core sample 2, due to the existence of coarse organic residues, sediments with Aeolian origin are more easily detectable than core sample1 but in lesser amounts. Through top $30 \mathrm{~cm}$, fine, rounded, windblown sediments superimposed of organic tissues were observed clearly although they weren't mineralogically recognizable (Figure 4(a)). Through top $30 \mathrm{~cm}$ of core sample 2, organic residues in early stages of decomposition were observed. As Aeolian particles were overlying these almost newly deposited organic remnants, it could be concluded that windblown fine grain particles are related to recently increased dust activities in the Hashilan Wetland watershed. Results of mineralogical analysis of the core sample 2 showed that clay minerals were prominent in the sample.

\subsection{Micromorphological Analysis of Core Sample 3}

Thin section studies of core sample 3 showed that upper $10 \mathrm{~cm}$ had a high c/f ratio compared to the depth 10 $30 \mathrm{~cm}$. considering the porosity of $50 \%-60 \%$ of part 3-1, it seems that a big part of the deposited fine sediments have been moved to the lower depths through pores system. Mineralogical analysis revealed that clay minerals
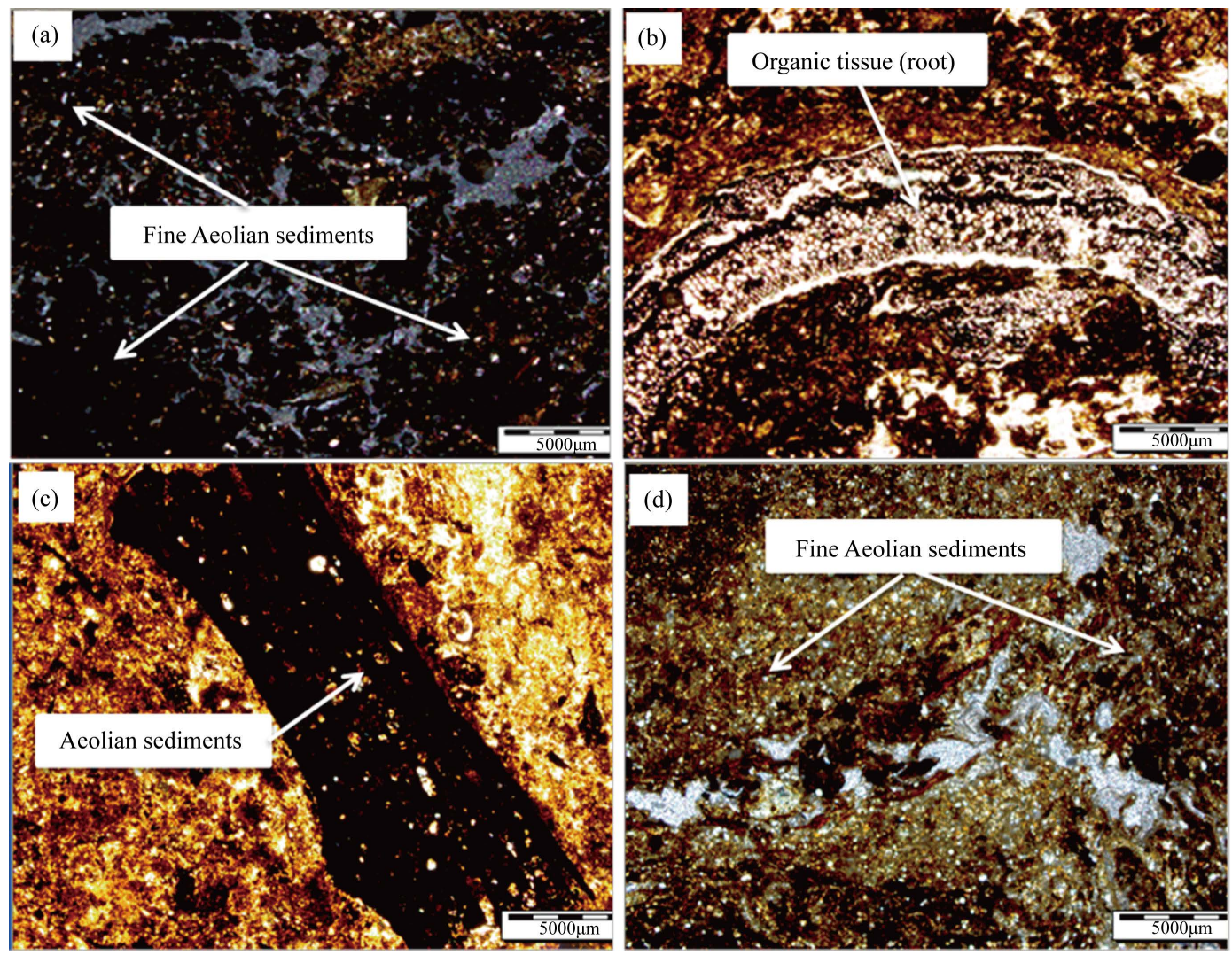

Figure 4. Thin section image of the core sample 2 under polarized right. (a) and (b) Part 2-1 (0 - $10 \mathrm{~cm})$ : fine Aeolian sediments superimposed organic tissues, organic residues and related pores; (c) and (d) Part 2-2 (10 $20 \mathrm{~cm}$ ): fine Aeolian sediments superimposed organic tissues and in the ground mass. 
were the common ones in the whole of the core sample and quartz minerals were rarely seen in the fine fraction. In the other words, minerals with the fine silt size (5 micrometer) were dominant in the micromass.

According to the results, particles with Aeolian origin were more common in the core sample 3 than other three samples (Figure 5(b) to Figure 5(f)). This could be related to the location of the sample 3. It was placed in the part of the Hashilan Wetland where the vegetation cover was lower than the other parts of the wetland (Table 2). Therefore, dust particles could easily be penetrated and deposited on the underlay sediments, resulting in increased amounts of fine grained sediments in the core sample 3. In other words, the lesser the organic matter content, the higher the amount of Aeolian sediments in the core sample. Like other three core samples, there wasn't a significant difference in the composition and type of the particles in various parts of the sample.

\subsection{Micromorphological Analysis of Core Sample 4}

In the core sample 4, texture varied from clay loam in the upper layers to sandy clay loam and loam in the lower parts (Table 2). c/f ratio didn't vary significantly through whole of the core sample 4 and its coincidence with
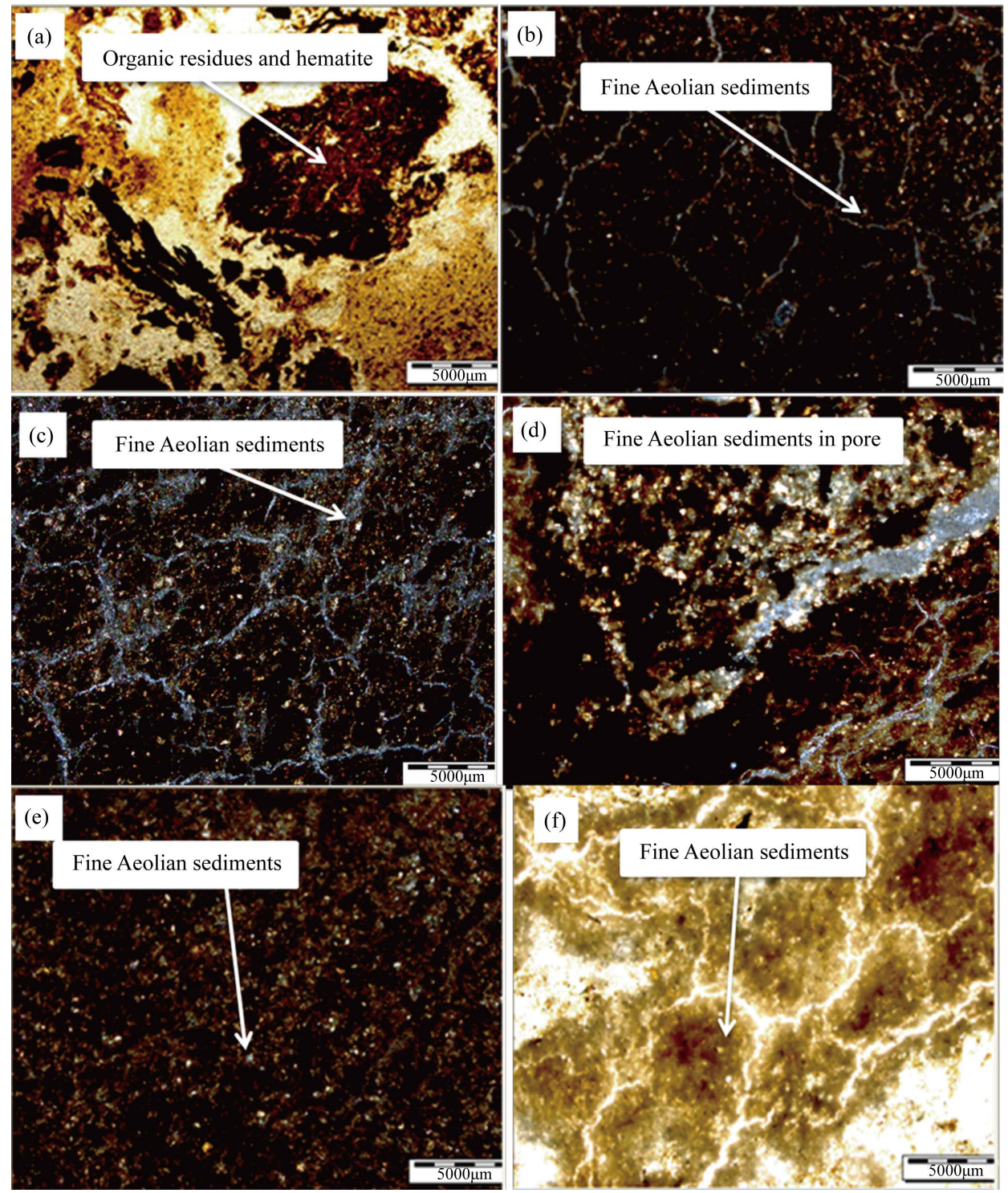

Figure 5. Thin section images of core sample 3. (a) and (b) Part 3-1 (0 - $10 \mathrm{~cm})$ : fine Aeolian particles over organic residues; (c) and (d) Part 3-2 (10 - 20): fine Aeolian sediments in pores; (e) and (f) Part 3-3 (20 - 30): Aeolian particles inside pores and over organic residues in PPL (E) and XPL (F). 
high dg (Table 2), proved that Aeolian fine grain particles in this sample aren't as common as they are in the other core samples. Considering the amount of organic matter in the sample, it could be said that increased amount of vegetation cover in sampling location has resulted in reduced amounts of Aeolian sediments, due to the restriction of plants in dust deposition to the underlay sediments in lakes and wetlands.

In part 4-3, coarse organic fibers and filaments were clearly observable (Figure 6(c)). Medium to fine grain quartz had the highest concentration in layer 4-1 (Figure 6(a)). Considering their different shape and size, it is possible that they have both alluvial and Aeolian origin (Evans et al., 2004). Particles with Aeolian origin had the lowest amount in comparison to other core samples. According to X-ray analysis, minerals didn't have significant variation in type or composition through different parts of the sample. Thin section studies revealed that organic residues with high degrees of decomposition were common in depth $30-70 \mathrm{~cm}$ which shows that there were wetter periods with higher vegetation cover in the past climate of the study area.

\subsection{X-Ray Analysis of Core Sample 1}

X-ray analysis of core sample1 showed that the dominant minerals in the coarse fraction were quartz and calcite; and chlorite, albite, mica-Illite and Pyrophyllite were the common ones in the fine fraction of the top $30 \mathrm{~cm}$ of the sample. In Mg-saturated treatment, 14.2, 7 and 3.5 angstrom picks were observed and these picks also remained in heated-K and Mg-glycerol treatments, proving the chlorite existence in the sample (Figure 7). The presence of 3.3 angstrom pick in $\mathrm{Mg}$, Mg-glycerol and heated $\mathrm{K}$ treatments, confirmed the existence of quartz minerals. Also appearance of 10, 5 and 3.3 angstrom picks in Mg-treatment and their remains in heated-K and Mg-glycerol treatments proved that Illite minerals also exist in the sample. 9 angstrom pick in Mg, Mg-glycerol and heated $\mathrm{K}$ was related to Pylophillite minerals.

These results were in accordance with the X-ray analysis of Kermanshah Dust samples which revealed that quartz and calcite were the common minerals in dust samples.

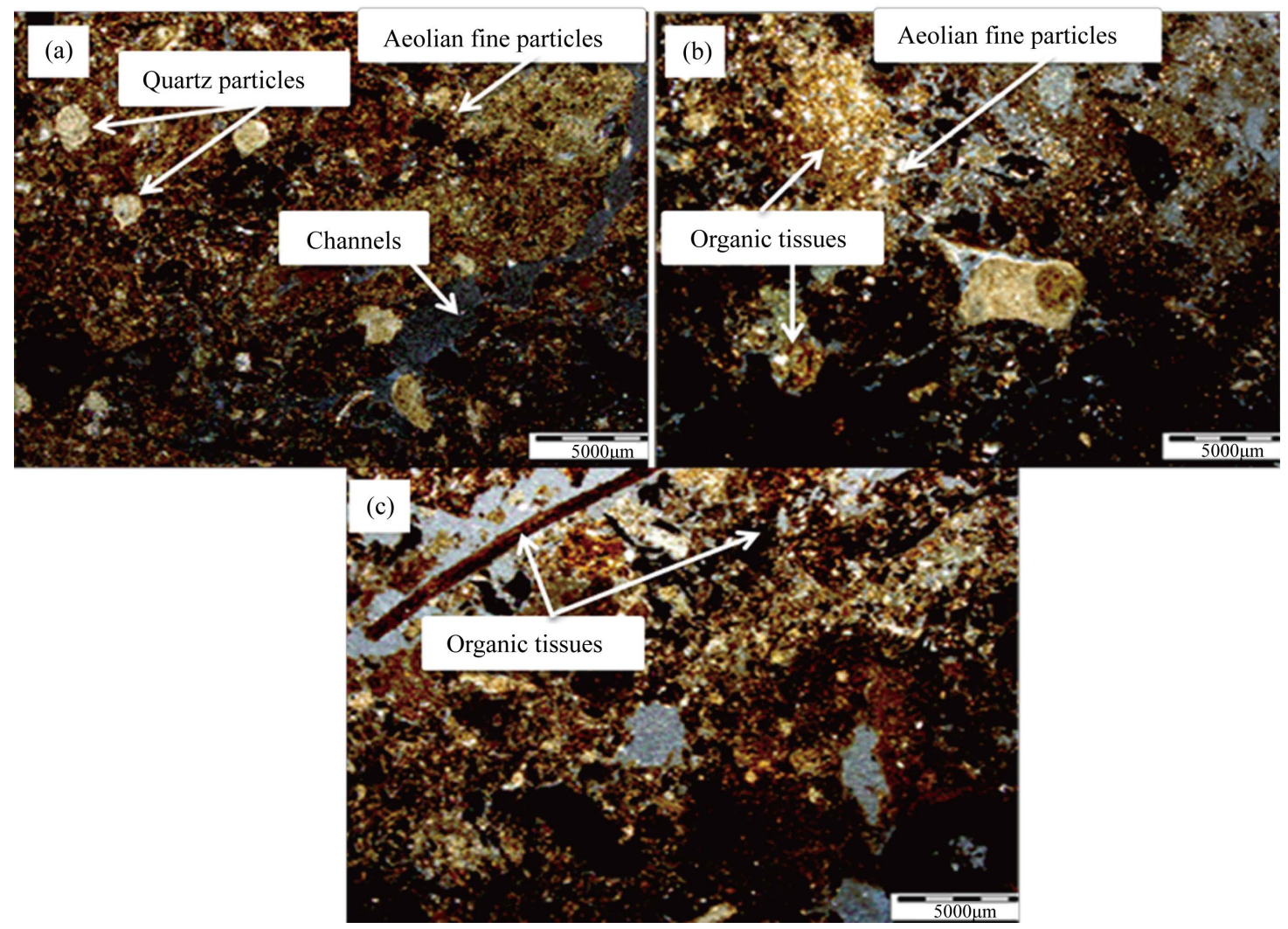

Figure 6. Thin section images of core sample 4 in PPL light. (a) Part 4-1 (0 - $10 \mathrm{~cm})$ : fine Aeolian particles and quartz minerals in different; (b) Part 4-2 (10 - $20 \mathrm{~cm}$ ): fine Aeolian sediments over organic residues; (c) Part 4-3 (20 - $30 \mathrm{~cm})$ : decomposed and semi-decomposed organic tissues and overlay Aeolian sediments. 


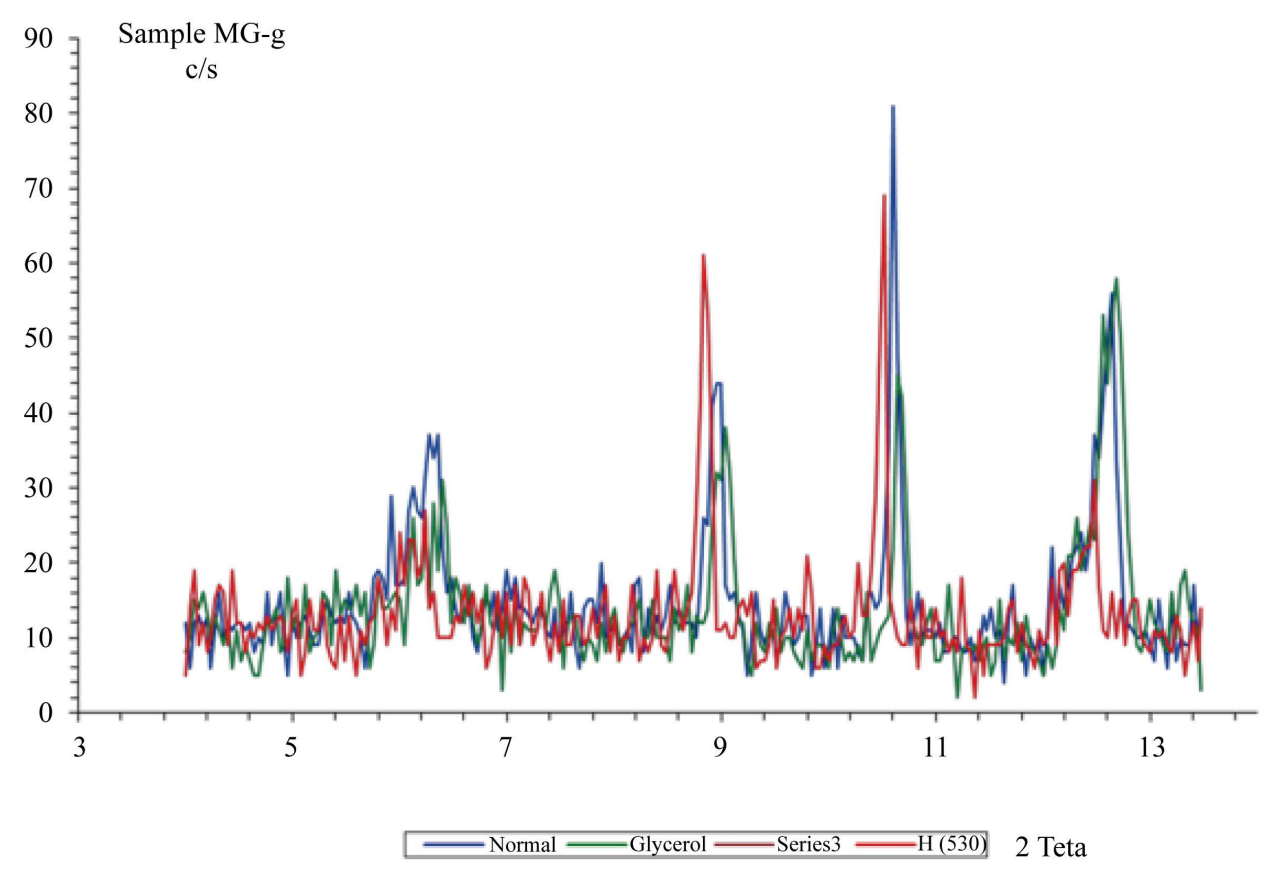

Figure 7. Diffractogram of detected minerals in core sample 1.

\subsection{SEM Analysis of Core Sample 1}

SEM images of core sample 1 and dust samples from Kermanshah dust measurement station were compared considering the type, size and mineralogy of Aeolian particles. Particles with round, irregular, crystalline and cylindrical shapes were observed in both samples, but they were clearer in core sample 1 (Figure 8). These shapes were the representative of clay minerals, quartz and calcite in the samples [23].

Round particles with 5 micrometer size were clay minerals and formed clustered shape in some of the images (Figure 8). Individual, round or irregular Particles with 10 - 20 micrometer size were assumed to be quartz and those with crystalline shape were detected as calcite. These minerals had the same size and shape in both core sample1 and dust samples from Kermanshah. Therefore it could be said that fine, rounded particles with $10-20$ micrometer at top $30 \mathrm{~cm}$ of core sample 1 could also have the same Aeolian origin as Kermanshah dust samples. As mineralogical and micromorphological studies of other core samples revealed that quartz and calcite particles with 10 - 20 micrometer size were dominant at top $30 \mathrm{~cm}$ of samples, it could be concluded that these fine particles in all of the core samples have also Aeolian origin. It should be mentioned that filaments seen in Kermanshah Dust sample images are related to dust trap filters strings (Figure 7(b) and Figure 7(d)).

These findings are in accordance with results from dust mineralogy in Riyadh which showed that quartz and calcite were the dominant minerals in dust samples [24]. Chemical and mineralogical studies of dust in west and southwestern Iran by [25] also revealed that calcite and quartz were common minerals in dust samples.

\subsection{Kermanshah Dust Measurement Station}

Figure 9 represents the number of days in which particles with 10 micrometer size (PM10) are above the pollutants standard index (PSI) during 2004 to 2011. According to Figure 7, between 2006 and 2009 the number of days with high PSI have increased with a sharp slope and in 2011, 120 days were out of standard.

In Figure 10, number of days in which dust storms has occurred during past 15 years are shown. According to the figure, number of days with dust storms has suddenly increased between 2007 and 2009 and has remained so afterwards.

According to these results, dust storms in Kermanshah have increased during past years. These results are in accordance with the findings from core sample analysis which showed that fine Aeolian particles are more common in upper layers of samples. Existence of these particles on organic tissues in early stages of decomposition proved that these Aeolian particles are very recently deposited. 

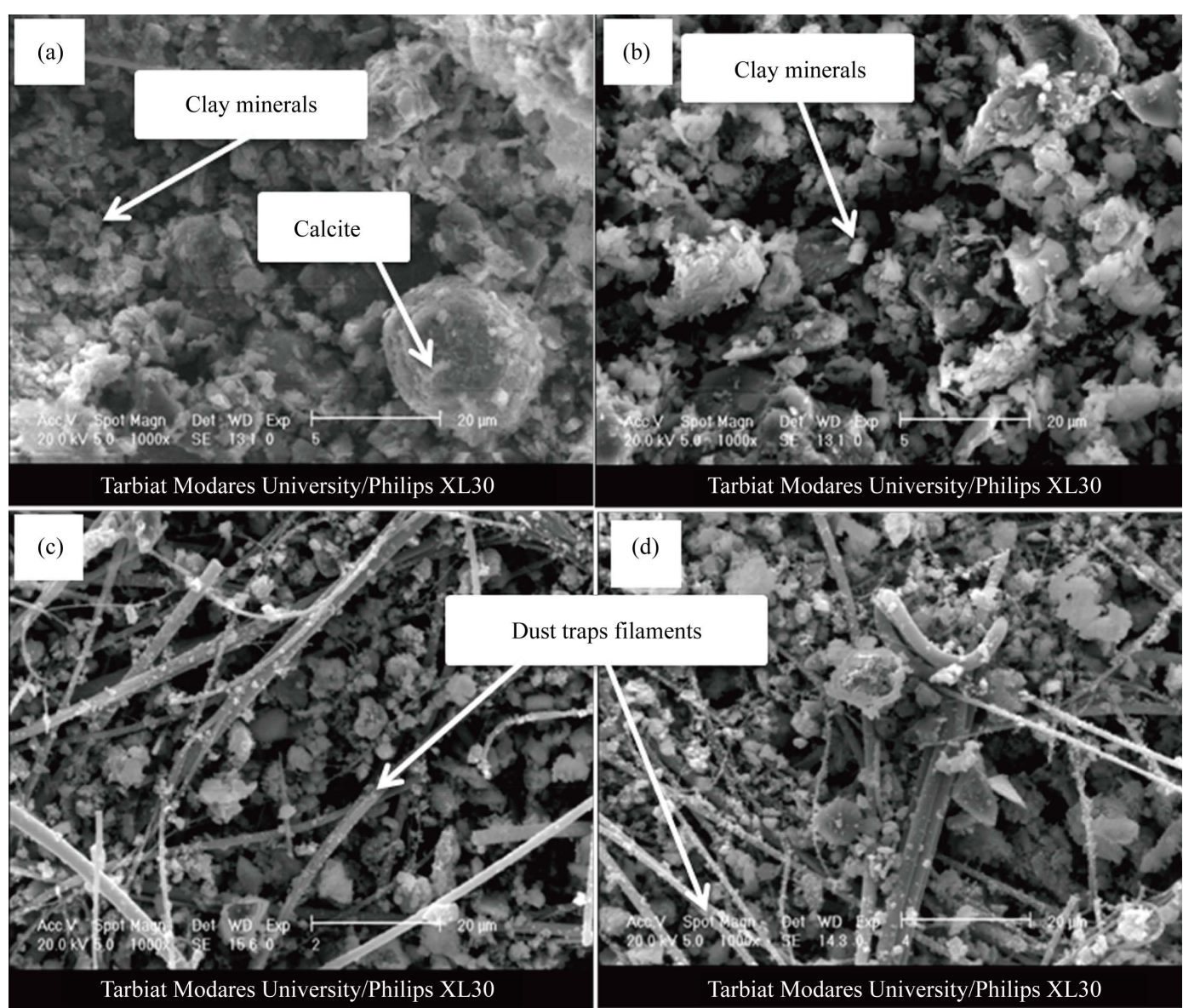

Figure 8. SEM images from core sample 1 and Kermanshah dust measurement station. (a) Quartz and clay minerals in core sample 1; (b) Clay minerals and calcite in core sample 1; (c) Quartz mineral in Kermanshah dust sample; (d) Clay minerals and calcite in Kermanshah dust sample.

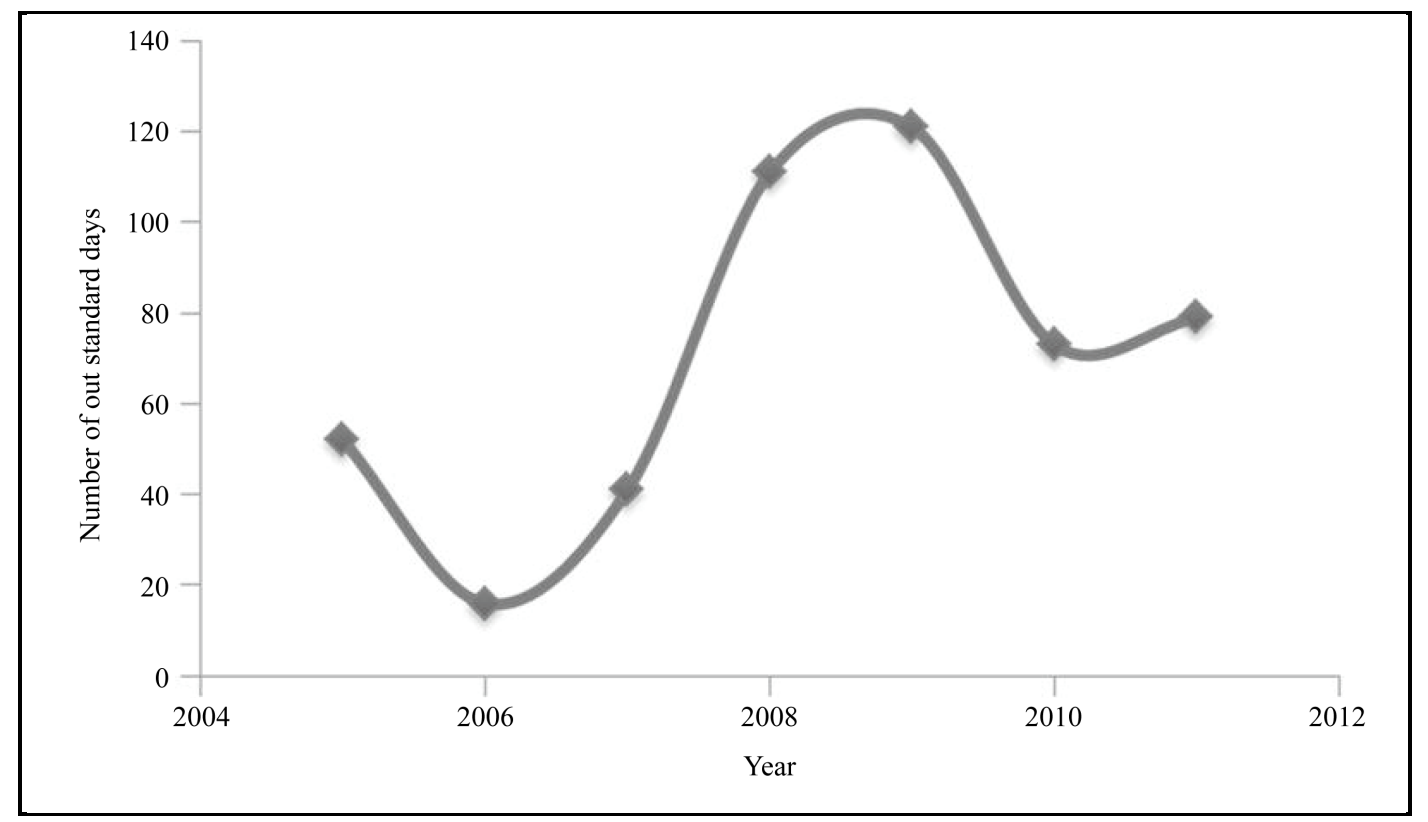

Figure 9. Number of days in those dust particles in air were higher than pollutant standard index in Kermanshah. 


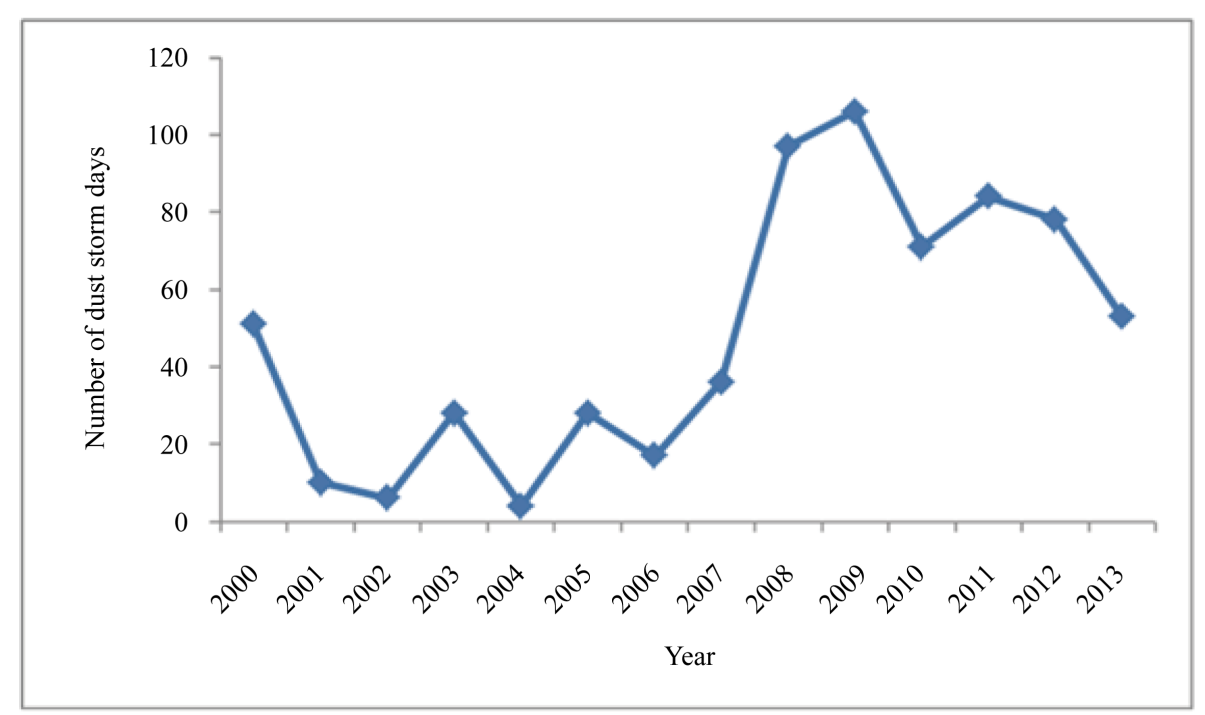

Figure 10. Number of days with dust storms between 2000 to 2013 in Kermanshah.

\section{Conclusions}

Core samples 1, 2, 3 and 4 had the highest volume of Aeolian sediments respectively. Considering the variation in amounts of windblown particles among four samples, it seemed that the location of the samples in Hashilan Wetland was a decisive factor on degree of penetration of dust particles into underlay sediments. Results showed that kind and type of dust particles didn't have significant variation among and through samples. Therefore, it could be concluded that deposited dust sediments had the same intra and extra origins during past years.

Thin section studies and SEM analysis revealed that grain size of most of the deposited dust particles at top 30 $\mathrm{cm}$ in almost all core samples was between 2 to 50 micrometres which was fine to coarse silt. According to mineralogical studies, clay minerals, quartz and calcite were the dominant minerals in core samples respectively.

In all four core samples, fine, rounded sediments with Aeolian origin were more common at top $30 \mathrm{~cm}$ than the deeper parts of the samples. Results also showed that nearly 30 to 40 percent of the thin sections at top 30 cm were occupied with non-organic minerals with alluvial or Aeolian origins. These findings were in accordance with the results from Kermanshah dust measurement station which had shown that entrance of dust from Iran's western neighbors had increased significantly during past 10 years. Therefore, as the identified sediments with Aeolian origin seemed to be uniform through all of the core samples, and their size, shape and mineralogical composition were in accordance with samples from dust traps in the area, it was worth saying that although water scarcity and desertification were real concerns in Iran, still dust particles with extra-regional origins were the main dust sources in the area.

\section{References}

[1] Pye, K. (1987) Aeolian Dust and Dust Deposits. Academic Press, London, 334.

[2] Prospero, J.M. and Lamb, P.J. (2003) African Droughts and Dust Transport to the Caribbean: Climate Change Implications. Science, 302, 1024-1027. http://dx.doi.org/10.1126/science.1089915

[3] Shao, Y., Wyrwoll, K.H., Chappell, A., Huang, J., Lin, Z., McTainsh, G.H., Mikami, M., Tanaka, T.Y., Wang, X. and Yoon, S. (2011) Dust Cycle: An Emerging Core Theme in Earth System Science. Aeolian Research, 2, 181-204. http://dx.doi.org/10.1016/j.aeolia.2011.02.001

[4] Bouchani, F. and Fazeli, D. (2011) Environmental Consiquences of Dust in West Iran. Quarterly Policy Journal, 2, 127-128.

[5] Kim, K.H., Choi, G.H., Kang, C.H., Lee, J.H., Kim, J., Youn, Y. and Lee, S. (2003) The Chemical Composition of Fine and Coarse Particles in Relation with the Asian Dust Events. Atmospheric Environment, 37, 753-765. http://dx.doi.org/10.1016/S1352-2310(02)00954-8

[6] Xuan, J., Sokolik, I.N., Hao, J., Guo, F., Mao, H. and Yang, G. (2004) Identification and Characterization of Sources of Atmospheric Mineral Dust in East Asia. Atmospheric Environment, 38, 6239-6252. 
http://dx.doi.org/10.1016/j.atmosenv.2004.06.042

[7] Wang, S., Yuan, W. and Shang, K. (2006) The Impacts of Different Kinds of Dust Events on PM 10 Pollution in Northern China. Atmospheric Environment, 40, 7975-7982. http://dx.doi.org/10.1016/j.atmosenv.2006.06.058

[8] Tsolmon, R., Ochirkhuyag, L. and Sternberg, T. (2008) Monitoring the Source of Transnational Dust Storms in North East Asia. International Journal of Digital Earth, 1, 119-129. http://dx.doi.org/10.1080/17538940701782593

[9] Wang, H., Jia, X., Li, K. and Li, Y. (2015) Horizontal Wind Erosion Flux and Potential Dust Emission in Arid and Semiarid Regions of China: A Major Source Area for East Asia Dust Storms. Catena, 133, 373-384. http://dx.doi.org/10.1016/j.catena.2015.06.011

[10] Akbary, M. and Farahbakhshi, M. (2015) Analysing and Tracing of Dust Hazard in Recent Years in Kermanshah Province. International Journal of Environmental Research, 9, 673-682.

[11] Cao, H., Amiraslani, F., Liu, J. and Zhou, N. (2015) Identification of Dust Storm Source Areas in West Asia Using Multiple Environmental Datasets. Science of the Total Environment, 502, 224-235. http://dx.doi.org/10.1016/j.scitotenv.2014.09.025

[12] Davari, M. (2013) Environmental Effects of Dust Hazard in Kordestan Province, Iran. 13th Iranian Soil Science Congress, Shahid Chamran University, Iran, 27-27 January, 2015.

[13] Beierle, B. and Smith, D.G. (1998) Severe Drought in the Early Holocene (10,000-6800 BP) Interpreted from Lake Sediment Cores, Southwestern Alberta, Canada. Palaeogeography, Palaeoclimatology, Palaeoecology, 140, 75-83. http://dx.doi.org/10.1016/S0031-0182(98)00044-3

[14] Evans, R., Jefferson, I., Kumar, R., O’Hara-Dhand, K. and Smalley, I. (2004) The Nature and Early History of Airborne Dust from North Africa; in Particular the Lake Chad Basin. Journal of African Earth Sciences, 39, 81-87. http://dx.doi.org/10.1016/j.jafrearsci.2004.06.001

[15] Petherick, L.M., McGowan, H.A. and Kamber, B.S. (2009) Reconstructing Transport Pathways for Late Quaternary Dust from Eastern Australia Using the Composition of Trace Elements of Long Traveled Dusts. Geomorphology, 105, 67-79. http://dx.doi.org/10.1016/j.geomorph.2007.12.015

[16] Costantini, E., Priori, S., Urban, B., Hilgers, A., Sauer, D., Protano, G., Trombino, L., Hülle, D. and Nannoni, F. (2009) Multidisciplinary Characterization of the Middle Holocene Eolian Deposits of the Elsa River Basin (Central Italy). Quaternary International, 209, 107-130. http://dx.doi.org/10.1016/j.quaint.2009.02.025

[17] Xu, J., Hou, S., Qin, D., Kaspari, S., Mayewski, P.A., Petit, J.R., Delmonte, B., Kang, S., Ren, J. and Chappellaz, J. (2010) A 108.83-m Ice-Core Record of Atmospheric Dust Deposition at Mt. Qomolangma (Everest), Central Himalaya. Quaternary Research, 73, 33-38. http://dx.doi.org/10.1016/j.yqres.2009.09.005

[18] Woronko, B. (2012) Late-Holocene Dust Accumulation within the Ancient Town of Marea (Coastal Zone of the South Mediterranean Sea, N Egypt). Quaternary International, 266, 4-13. http://dx.doi.org/10.1016/j.quaint.2011.09.010

[19] Kutuzov, S., Shahgedanova, M., Mikhalenko, V., Ginot, P., Lavrentiev, I. and Kemp, S. (2013) High-Resolution Provenance of Desert Dust Deposited on Mt. Elbrus, Caucasus in 2009-2012 Using Snow Pit and Firn Core Records. The Cryosphere, 7, 1481-1498. http://dx.doi.org/10.5194/tc-7-1481-2013

[20] Zarasvandi, A., Carranza, E., Moore, F. and Rastmanesh, F. (2011) Spatio-Temporal Occurrences and MineralogicalGeochemical Characteristics of Airborne Dusts in Khuzestan Province (Southwestern Iran). Journal of Geochemical Exploration, 111, 138-151. http://dx.doi.org/10.1016/j.gexplo.2011.04.004

[21] Hojati, S., Khademi, H., Cano, A.F. and Landi, A. (2012) Characteristics of Dust Deposited along a Transect between Central Iran and the Zagros Mountains. Catena, 88, 27-36. http://dx.doi.org/10.1016/j.catena.2011.09.002

[22] Mahmodi, Z. and Khademi, H. (2012) The Recognition of Atmospheric Dust Origins in Isfahan Using Chemical and Mineralogical Properities of Dust. Water and Soil Conservation Researches, 21, 1-18.

[23] Rashki, A., Eriksson, P.G., Rautenbach, C.D. W., Kaskaoutis, D.G., Grote, W. and Dykstra, J. (2013) Assessment of Chemical and Mineralogical Characteristics of Airborne Dust in the Sistan Region, Iran. Chemosphere, 90, 227-236. http://dx.doi.org/10.1016/j.chemosphere.2012.06.059

[24] Modaihsh, A. (1997) Characteristics and Composition of the Falling Dust Sediments on Riyadh City, Saudi Arabia. Journal of Arid Environments, 36, 211-223. http://dx.doi.org/10.1006/jare.1996.0225

[25] Khoshakhlagh, F., Najafi, M.H., Zamanzadeh, S.M., Shirazi, M.H. and Samadi, M. (2013) The Study of the Composition of Dust in West and Southwest Iran. Geography and Environmental Hazards, 6, 17-36. 